International Journal of Business Management and Economic Review

Vol. 4, No. 04; 2021

ISSN: 2581-4664

\title{
THE EFFECT OF MICRO AND MACRO VARIABLES ON STOCK RETURN
}

\author{
I Putu Budiantara and Luh Putu Wiagustini \\ Faculty of Economics and Business, Udayana University, Bali, Indonesia
}

http://doi.org/10.35409/IJBMER.2021.3292

\begin{abstract}
The purpose of this study was to analyze the significance of the effect of micro and macro variables on stock returns of multinational companies listed on the Indonesia Stock Exchange, Frankfurt Stock Exchange and New York Stock Exchange. The population of this study are multinational companies that are listed on the three stock exchanges, namely the Indonesia Stock Exchange, the Frankfurt Stock Exchange, and the New York Stock Exchange, totaling 7 companies. Determination of the sample using the census method, namely the entire population is observed. This research uses Multiple Linear Regression analysis technique. The results of the study found that partially the relationship between the independent and dependent variables was not always the same in the three capital markets studied. ROE has a positive effect on stock returns in all capital markets studied (IDX, DAX, and NYSE). EPS has a positive effect on stock returns on the NYSE, but has no effect on IDX and DAX. DER has a negative effect on stock returns studied in the IDX capital market, but has no effect on DAX and NYSE. GDP has no effect on stock returns in all capital markets studied (IDX, DAX, and NYSE). Interest rates have a positive effect on stock returns on the NYSE but have no effect on stock returns on IDX and DAX.
\end{abstract}

Keyword: Return on Equity, Earning Per Share, Debt to Equity Ratio, Gross Domestic Product, Interest Rate, Stock Return.

\section{INTRODUCTION}

Micro fundamental analysis is an analysis used to calculate the value of shares using the company's financial data, then processed according to the needs of the analysis to determine the company's financial ratios, so that the value of these financial ratios will be able to know the value of a company's shares (Jogiyanto, 2015). Macro fundamental analysis is an analysis that is used to calculate stock values using data that is outside the company and not under the control of the company's management (Egbunike and Okerekeoti, 2018).

Micro variables are calculated using financial ratios, financial ratios are used to analyze finance and accounting, information becomes data that can be easily compared. Examination of this ratio can help assess the financial health of a company. Financial ratios are an excellent tool for understanding whether a company's performance is improving or declining. Financial ratios will show all financial aspects, such as liquidity, solvency, and profitability (Allozi and Obeidat, 2016). Return On Equity (ROE) is a financial ratio used to measure the company's rate of return or the company's effectiveness in generating profits. ROE as a research variable because 


\section{International Journal of Business Management and Economic Review}

Vol. 4, No. 04; 2021

ISSN: 2581-4664

according to Caroline (2020) ROE is a special measure for shareholder ownership and business owners.

ROE is a ratio to measure the ability to generate profits by measuring the return on own capital. Return on Equity (ROE) can be calculated by comparing net income with shareholder equity. Return on Equity (ROE) measures the income of shareholders for their investment in the company (Anwaar, 2016). The results of previous studies show that ROE has a significant positive effect on stock returns (Allozi and Obeidat (2016), Nurhikmawaty et al., (2020), Anita and Negoro (2019), and Hendrawan and Avitianti (2018)). This finding is in accordance with the Signaling Theory (Spence, 1973) which shows that a high ROE is a signal for investors about the company's prospects in the future, this condition has an impact on stock demand thereby increasing stock returns. But a different study was found by Caroline (2020) which stated that ROE had no effect on stock returns, the same finding was also found by Hertina and Saudi (2019) and Sami (2018) that Return On Equity was not significantly related to stock returns.

Earning Per Share (EPS) is a financial ratio that measures the ratio of profits earned by the company to the number of shares. EPS describes as a market ratio that shows how much profit investors or shareholders will benefit from each share (Sami, 2018) A high EPS value indicates a good company performance, so that it becomes a signal for investors for the company's prospects in the future, this condition has an impact on on stock demand so that the stock price rises. Earning Per Share (EPS) can be calculated by comparing the amount of income and the number of company shares (Hertina and Saudi, 2019). EPS shows the amount of net profit that is ready to be distributed to shareholders and can be calculated by dividing net income by the number of shares outstanding (Anita and Negoro, 2019).

Allozi and Obeidat (2016) found that EPS financial ratios had a significant positive effect on stock returns as a proxy for firm value. The same results were also found by Hertina and Saudi (2019) and Sami (2018) which showed Earning Per Share had a positive effect on stock returns. This finding is in accordance with the Signaling Theory (Spence, 1973) which shows that high EPS is a signal for investors for the company's prospects in the future, this condition has an impact on stock demand thereby increasing stock returns. But a different study found that EPS had a significant negative impact on stock returns (Anwaar, 2016). EPS partially has no significant effect on stock returns (Sausan et al., 2020) and (Aryaningsih et al., 2018).

Capital structure is a very important factor for company growth. The capital structure has a strategic influence on the achievement of the company's long-term goals. On the other hand, corporate funding decisions are a very complex process. One measure of capital structure is the Debt to equity ratio (DER). Ratih and Chandradewi (2020) DER is a measure of a company's financial leverage, which shows the amount of debt and equity used to finance the company's assets. DER is the ratio between debt and equity. Ratios can provide information about the capital structure of a company (Kamar, 2017). Debt to equity ratio (DER) describes how much the company uses funding through debt and how much the company's ability to meet its obligations. Debt to equity ratio (DER) is used as a measure of leverage, because this ratio shows the percentage of debt used by the company.

Research shows that DER has a positive effect on stock returns (Hertina and Saudi, 2019; Tascha and Mustafa 2021), this condition shows that the higher the debt used, investors see that there are prospects for company development, the higher the demand for shares which have an impact on stock returns. This finding supports the Capital Structure Theory from Modigliani and Miller 


\section{International Journal of Business Management and Economic Review}

Vol. 4, No. 04; 2021

ISSN: 2581-4664

(1958) in Brigham and Daves (2019) where the higher the capital structure, the higher the firm value as a result of tax savings on the use of debt. DER shows the company's capital structure. Different research results state that DER was found to have a significant negative effect on stock returns by Basarda et al., (2018), and Sausan et al., (2020), DER was found to have no significant effect on stock returns by Nurhikmawaty et al., (2020). The same research was found by Allozi and Obeidat (2016) and Ratih and Chandradewi (2020).

Macro variables used in this study include Gross Domestic Product (GDP) or gross domestic product (GDP), GDP measures the value of final goods and services. Final goods are all commodities currently produced, exchanged and consumed although this definition is controversial. GDP is an indicator of a country's economic performance (Thrun, 2019). Gross domestic product is the final value of a good or service produced in one year. The GDP growth rate is an important indicator of a country's economic performance and GDP is one way of calculating national income (Sasono, 2020).

Research conducted by Anita and Negoro (2019) shows that Gross Domestic Product has a positive and insignificant effect on stock prices. GDP was found to have a significant positive effect on stock returns (Hendawan and Avitianti, 2018). This finding is in accordance with the Signaling Theory (Spence, 1973) which shows that high GDP is a signal for investors for the company's prospects in the future, this condition has an impact on stock demand so that stock prices rise. This condition indicates that an increase in GDP indicates an increase in people's income which can increase the demand for shares, thereby increasing stock returns. However, on the other hand, GDP was found to have no effect on stock returns by Ratih and Chandradewi (2020), Tascha and Mustafa (2021), and Chasanah (2021) who concluded that Gross Domestic Product / GDP had no significant effect on stock returns.

Interest rates are important because they control the flow of money in the economy. High interest rates reduce inflation but also slow down the economy. Low interest rates boost the economy, but can cause inflation (Egbunike and Okerekeoti, 2018). Jayashankar and Rath (2017) find interest rates and stock returns show a negative relationship, this finding is in accordance with Signaling Theory (Spence, 1973) which shows that low interest rates are a signal for investors to invest in company shares in the future, This condition has an impact on stock demand thereby increasing stock returns. Vice versa when increasing an interest rate makes investors will be more interested to put money in the bank to obtain a higher return than investing in stocks. The same study found by Lawrence and Avitianti (2018) and Khan et al., (2018) that there is a negative and significant effect between interest rates and stock returns. Different studies found by Basarda et al., (2018), Dwi and Ward (2019) and Akbar (2019) stated interest rates and a significant positive effect on stock returns. Lawrence and Avitianti (2018), and Rafiq et al., (2019) which states that interest rates partially no significant effect on stock returns.

\section{LITERATURE REVIEW AND HYPOTHESES DEVELOPMENT}

Research conducted by Allozi and Obeidat (2016) shows that Return on Equity has a significant positive effect on stock returns, research conducted by Nurhikmawaty et al., (2020) shows the results that Return on Equity (ROE) has a significant positive effect on returns. share. According to Anita and Negoro (2019), it shows that return on equity has a positive and significant effect on stock prices. The higher the ROE means the better the company's performance in managing capital to generate profits for shareholders, thereby increasing stock returns. This finding is in 


\section{International Journal of Business Management and Economic Review}

Vol. 4, No. 04; 2021

ISSN: 2581-4664

accordance with the Signaling Theory (Spence, 1973) which shows that a high ROE is a signal for investors for the company's prospects in the future, this condition has an impact on stock demand so that stock returns rise. Caroline (2020) stated that ROE had no effect on stock returns, the same finding was also found by Hertina and Saudi (2019) and Sami (2018) that Return On Equity was not significantly related to stock returns.

H1: Return on Equity (ROE) has a positive effect on stock returns.

Research conducted by Allozi and Obeidat (2016) shows that EPS financial ratios have a significant relationship with stock returns derived from profitability measures, the same results are also found by Hertina and Saudi (2019) research which states that Earning Per Share has a positive effect on stock returns, Earning Per Share is described as a market ratio that shows how much return investors or shareholders will benefit from each share, research by Sami (2018) shows Earning Per Share has a positive and significant influence related to stock returns. Anita and Negoro (2019) showed that Earning Per Share has a significant positive effect on stock returns. This finding is in accordance with the Signaling Theory (Spence, 1973) which shows that high EPS is a signal for investors for the company's prospects in the future, this condition has an impact on stock demand so that stock returns increase. Different studies found that EPS had a significant negative impact on stock returns (Anwaar, 2016). EPS partially has no significant effect on stock returns by Sausan et al., (2020) and Aryaningsih et al., (2018).

H2: Earning Per Share (EPS) has a positive effect on stock returns.

Research conducted by Basarda et al., (2018) states that DER has a negative effect on stock returns. So that every increase in DER will reduce stock returns. Based on the results of the analysis also shows the level of company debt, companies with large debts have large debt costs as well. So this becomes a burden for companies that can reduce the level of investor confidence. Investors tend to avoid stocks with high Debt to Equity Ratio / DER values. The same study was found by Sausan et al., (2020) which stated that DER had a negative and significant effect on stock returns. This research is in accordance with the Trade off Theory because the increasing use of corporate debt will experience financial difficulties so that investors tend to sell their shares.

Different studies show that DER has a positive effect on stock returns (Hertina and Saudi, 2019; Tascha and Mustafa, 2021). This condition shows that the higher the debt used, investors see that there are prospects for company development, the higher the demand for shares which have an impact on stock returns. This finding supports the Capital Structure Theory from Modigliani and Miller (1958) where the higher the capital structure, the higher the firm value as a result of tax savings on the use of debt. DER shows the company's capital structure.

H3: Debt to Equity Ratio (DER) has a negative effect on stock returns.

Research conducted by Anita and Negoro (2019) shows that Gross Domestic Product has a positive and insignificant effect on stock prices. Hendrawan and Avitianti's research (2018) shows that GDP partially has a significant effect on stock returns. This finding is in accordance with the Signaling Theory (Spence, 1973) which shows that high GDP is a signal for investors for the company's prospects in the future, this condition has an impact on stock demand so that stock prices rise. This condition indicates that the increase in GDP indicates an increase in people's income which can increase the demand for shares so that stock returns increase.

According to Ratih and Chandradewi (2020) The effect of Gross Domestic Product on stock returns shows that GDP has a negative and insignificant effect on stock returns. Tascha and 


\section{International Journal of Business Management and Economic Review}

Vol. 4, No. 04; 2021

ISSN: 2581-4664

Mustafa (2021), and Chasanah (2021) found that it had a negative and insignificant effect on stock returns.

H4: Gross Domestic Product (GDP) has a positive effect on stock returns.

The interest rate is the ratio of returns on a number of investments as a form of reward given to investors. The interest rate refers to the price charged by the lender to the borrower and is usually expressed as a percentage of the total amount. Interest rates can be charged annually, semiannually, quarterly or monthly, depending on the agreement between the lender and the borrower (Ahmad et al., 2019).

Research conducted by Jayashankar and Rath (2017) shows that interest rates and stock returns show a negative relationship. This study is consistent with previous studies in several countries and is also consistent with known facts about the inverse relationship between interest rates and stock prices. The same research found by Hendrawan and Avitianti (2018) shows that interest rates partially have no significant effect on stock returns. The negative relationship between the interest rate regression coefficients means that for each increase in interest rates for one unit will cause a decrease in stock returns. This finding is in accordance with the Signaling Theory (Spence, 1973) which shows that low interest rates are a signal for investors to invest in the company's stock prospects in the future, this condition has an impact on stock demand so that stock returns increase. Vice versa when an increase in interest rates makes investors more interested in putting their money in the bank to get a higher return than investing in stocks.

On the other hand, Basarda et al., (2018), Dwi and Wardoyo (2019), and Akbar (2019) found different things, namely interest rates have a positive effect on stock returns. According to AlAbdallah and ALjarayesh (2017) Interest rates have a significant influence on stock returns. H5: Interest rates have a negative effect on stock returns.

\section{METHODS}

This research is a quantitative research, so that in this research there are independent and dependent variables. The variable is then searched for how much influence the independent variable has on the dependent variable (Sugiyono, 2019). The study was conducted on the population or sample by taking samples of companies whose shares are traded on the Indonesia Stock Exchange (IDX), Frankfurt Stock Exchange and New York Stock Exchange. Stock selection is based on the idea of knowing the influence of micro and macro fundamental factors on stock returns, on the shares traded.

The time of the research starts from 2015 to 2019. The research is made thoroughly which includes things to be done starting from making hypotheses, operational implications, to the final analysis where the variables used are the dependent variable and the independent variable. nonparticipant observation methods and cross-sectional methods, non-participant observation methods, namely the researcher only as an observer of the object to be studied, without being directly involved, and the cross-sectional method which is a research conducted by taking a relatively short time and a certain place. Data obtained through the website with details, namely the company's financial statements published quarterly in the period 2015 to 2019 which were sampled in this study, data obtained through the website of the company concerned, stock trading reports on the Indonesia Stock Exchange, Frankfurt Stock Exchange and New York Stock Exchange which has been officially published through the website https://finance.yahoo.com, data on Gross Domestic Product / GDP, and data on interest rates in Indonesia, Germany, and the 
International Journal of Business Management and Economic Review

Vol. 4, No. 04; 2021

ISSN: 2581-4664

United States for the period 2015 to 2019, published by the official website of the World Bank (http://data.worldbank.org) using multiple linear regression analysis, the data that has been obtained is processed using a quantitative analysis tool in the form of SPSS 25.0.

\section{RESULTS AND DISCUSSION}

Hypothesis Testing Results

The results of multiple linear regression analysis for each capital market can be seen in Table 1 as follows:

Table 1. T-Test Results in Each Capital Market

\begin{tabular}{|c|c|c|c|c|c|c|c|c|c|c|c|}
\hline \multirow[t]{2}{*}{ No. } & \multirow[t]{2}{*}{$\begin{array}{l}\text { Capital } \\
\text { Market Name }\end{array}$} & \multicolumn{2}{|c|}{ ROE (X1) } & \multicolumn{2}{|c|}{ EPS (X2) } & \multicolumn{2}{|c|}{ DER (X3) } & \multicolumn{2}{|c|}{ PDB (X4) } & \multirow{2}{*}{$\begin{array}{l}\text { Interest } \\
\text { (X5) } \\
\mathrm{t}\end{array}$} & \multirow{2}{*}{$\begin{array}{l}\text { Rate } \\
\text { Sig. }\end{array}$} \\
\hline & & $\mathrm{t}$ & Sig. & $\mathrm{t}$ & Sig. & $\mathrm{t}$ & Sig. & $\mathrm{t}$ & Sig. & & \\
\hline \multirow[t]{2}{*}{1} & Indonesia & & & & & & & & & & \\
\hline & $\begin{array}{l}\text { Stock } \\
\text { Exchange } \\
\text { (IDX) }\end{array}$ & 7,724 & , 000 & $-0,616$ & ,539 & $-2,733$ & ,007 & 0,448 & ,655 & 0,202 & ,840 \\
\hline \multirow[t]{2}{*}{2} & Frankfurt & & & & & & & & & & \\
\hline & $\begin{array}{l}\text { Stock } \\
\text { Exchange } \\
\text { (DAX) }\end{array}$ & 9,194 & , 000 & $-0,335$ & ,738 & $-0,464$ & ,643 & 0,455 & ,650 & $-0,761$ & ,448 \\
\hline \multirow[t]{2}{*}{3} & New $\quad$ York & & & & & & & & & & \\
\hline & $\begin{array}{l}\text { Stock } \\
\text { Exchange } \\
\text { (NYSE) }\end{array}$ & 3,692 & ,000 & 2,155 & ,033 & 0,959 & ,339 &,- 502 & ,616 & 2,243 & ,027 \\
\hline
\end{tabular}

Secondary Data, 2021

Effect of Return on Equity on stock returns

H1 which states that Return On Equity / ROE has a positive and significant effect on stock returns and can be accepted in all capital markets studied, namely the Indonesian Stock Exchange / IDX, Frankfurt Stock Exchange / DAX, and New York Stock Exchange / NYSE, with respective significance values of IDX : $0.000(\mathrm{t}:+7,724)$, DAX: $0.000(\mathrm{t}:+9,194)$, and NYSE: $0.000(\mathrm{t}:+3.692)$.

The results of the analysis show that there is a positive effect of Return on Equity / ROE on stock returns on the Indonesia Stock Exchange / IDX, Frankfurt Stock Exchange / DAX, and the New York Stock Exchange / NYSE. This means that the micro variable in this case is Return on Equity, namely the company's ability to generate profits from equity or invested capital, which has an impact and can improve investors' decisions to invest in the Indonesia Stock Exchange / IDX, Frankfurt Stock Exchange / DAX, and New York. Stock Exchange / NYSE, this shows an increase in the value of Return on Equity / ROE will result in an increase in stock returns due to an increase in demand for these shares.

The findings of this study indicate that Return on Equity / ROE provides a signal for investors about the company's prospects in the future so that investors increase their investment in company shares on the Indonesia Stock Exchange / IDX, Frankfurt Stock Exchange / DAX, and the New York Stock Exchange / NYSE. This finding is in accordance with the Signaling Theory (Spence, 1973). The results of this study are in line with the results of research conducted by 


\section{International Journal of Business Management and Economic Review}

Vol. 4, No. 04; 2021

ISSN: 2581-4664

Allozi and Obeidat (2016), Nurhikmawaty et al., (2020), Anita and Negoro (2019), and Hendrawan and Avitianti (2018) which state that Return on Equity / ROE has an effect on positive on stock returns.

Effect of Earning Per Share on stock returns

H2 which states that Earning Per Share / EPS has a positive and significant effect on stock returns / stock returns is acceptable and is found only on the New York Stock Exchange / NYSE capital market which states that Earning Per Share / EPS has a positive and significant effect on stock returns / stock return with a significance value of NYSE: $0.033(\mathrm{t}:+2.155)$. But different results were found in the Indonesia Stock Exchange / IDX and Frankfurt Stock Exchange / DAX capital markets, the results of the analysis on the capital market studied stated that Earning Per Share / EPS had a negative and insignificant effect on stock returns / stock returns on Indonesia Stock. Exchange / IDX with a significance of 0.539 (t: -0.616), and Frankfurt Stock Exchange / DAX with a significance of 0.738 ( $t:-0.335)$.

The results of the analysis show that there is a positive effect of Earning Per Share / EPS on stock returns on the New York Stock Exchange / NYSE. This means that the micro variable in this case Earning Per Share / EPS is a ratio that describes the level of profit earned by shareholders and can improve investor decisions in investing in the New York Stock Exchange / NYSE, this shows an increase in the value of Earning Per Share / EPS will result in an increase in stock returns due to an increase in demand for these shares.

The findings of this study indicate that Earning Per Share / EPS provides a signal for investors about the company's prospects in the future so that investors increase their investment in the company's shares on the New York Stock Exchange / NYSE. This finding is in accordance with Signaling Theory (Spence, 1973). The results of this study are in line with the results of research conducted by Allozi and Obeidat (2016), Hertina and Saudi (2019), Sami (2018), and Anita and Negoro (2019) which state that Earning Per Share / EPS has a positive effect on stock returns.

The results of the analysis show that Earning Per Share / EPS has no effect on stock returns on the Indonesia Stock Exchange / IDX, and Frankfurt Stock exchange / DAX, this means that the micro variable in this case Earning Per Share / EPS cannot be used as a basis for determining returns. shares on the Indonesia Stock Exchange / IDX, and the Frankfurt Stock exchange / DAX. The results of this study are in line with the results of research conducted by Sausan et al., (2020), and Aryaningsih et al., (2018) which states that Earning Per Share / EPS has no effect on stock returns.

Effect of Debt to Equity Ratio on stock returns

H3 which states that the Debt to Equity Ratio / DER has a negative and significant effect on the stock return / stock return can be accepted on the Indonesian Stock Exchange / IDX capital market, with a significant value of IDX: 0.007 (t: -2.733). But different results were found in the Frankfurt Stock Exchange / DAX, and New York Stock Exchange / NYSE capital markets with the results of the analysis on the two capital markets studied stating that the Debt to equity ratio / DER had no significant effect on the stock return, with a value of respectively Frankfurt Stock Exchange/DAX: 0.643 (t: -0.464), and New York Stock Exchange/NYSE: 0.339 (t: +0.959).

The results of the analysis show that there is a negative effect of Debt to Equity Ratio / DER on stock returns on the Indonesia Stock Exchange / IDX. This shows that the increasing use of debt as seen from the Debt to Equity Ratio / DER will reduce stock returns, companies that increase debt are responded negatively by investors thereby reducing stock investment or increasing stock 


\section{International Journal of Business Management and Economic Review}

Vol. 4, No. 04; 2021

ISSN: 2581-4664

sales. The findings of this study indicate that the Debt to Equity Ratio / DER is in accordance with the Trade off Theory (Modigliani and Miller, 1963) because the increased use of corporate debt will experience financial difficulties so that investors tend to sell their shares. The results of this study support previous research conducted by Basarda et al., (2018), and Sausan et al., (2020).

The results of the analysis show that the Debt to Equity Ratio / DER has no effect on stock returns on the Frankfurt Stock Exchange / DAX, and the New York Stock Exchange / NYSE. This shows that the micro variable in this case the Debt to Equity Ratio / DER does not affect the decision of investors to invest in the capital market. The results of this study are strengthened by research conducted by Allozi and Obeidat (2016), Nurhikmawaty et al., (2020) and Ratih and Chandradewi (2020), which state that DER has no effect on stock returns.

Effect of Gross Domestic Product on stock returns

H4 which states that Gross Domestic Product / GDP has a positive and significant effect on stock returns / stock returns cannot be accepted in the three capital markets, namely the Indonesia Stock Exchange / IDX, Frankfurt Stock Exchange / DAX, and the New York Stock Exchange / NYSE with the results of the analysis of all capital markets studied state that Gross Domestic Product / GDP has no significant effect on stock returns, with a significance value of respectively Indonesia Stock Exchange / IDX: 0.655 ( $\mathrm{t}:+0.448)$, Frankfurt Stock Exchange / DAX: 0.650 (t: +0.455 ), and New York Stock Exchange/NYSE: 0.616 ( $\mathrm{t}:-0.502)$.

The results of the analysis show that Gross Domestic Product / GDP has no effect on stock returns on the Indonesia Stock Exchange / IDX, Frankfurt Stock Exchange / DAX, and the New York Stock Exchange / NYSE. This shows that the macro variable in this case Gross Domestic Product / GDP does not affect investors' decisions to invest in the capital market. Based on research results that have no effect, it means that not all people allocate their funds to invest. The results of this study are in line with previous research conducted by Ratih and Chandradewi (2020), Tascha and Mustafa (2021), and Chasanah (2021) which concluded that Gross Domestic Product / GDP has no effect on stock returns. 
International Journal of Business Management and Economic Review

Vol. 4, No. 04; 2021

ISSN: 2581-4664

Effect of Interest Rates on Stock Returns

H5 which states that interest rates have a negative and significant effect on stock returns / stock returns cannot be accepted on the Indonesian Stock Exchange / IDX, Frankfurt Stock Exchange / DAX, and New York Stock Exchange / NYSE capital markets with results on the New York Stock capital market Exchange / NYSE which states that interest rates have a positive and significant effect on stock returns with a significant value of NYSE: $0.027(\mathrm{t}:+2.243)$. However, different results were found in the Indonesian Stock Exchange / IDX and Frankfurt Stock Exchange / DAX capital markets which stated that interest rates had no significant effect on stock returns, with each significant value of IDX: $0.840(\mathrm{t}:+0.202)$, and DAX: $0.448(\mathrm{t}:-0.761)$. The results of the analysis show that there is a positive effect of interest rates on stock returns on the New York Stock Exchange / NYSE. This means that the macro variable in this case the interest rate can increase the decision of investors to invest in the New York Stock Exchange / NYSE, this shows that an increase in the value of interest rates will result in an increase in stock returns. The findings of this study indicate that interest rates provide a signal for investors about the company's prospects in the future, thereby increasing investment in the company's shares on the New York Stock Exchange / NYSE. This finding is in accordance with Signaling Theory (Spence, 1973). An important finding from this study is that interest rates are used as a preference for investors to invest in market capital. Positive changes in interest rates encourage investors to maintain their investments so that it has an impact on increasing stock prices and ultimately increasing stock returns. The results of this study are in line with the results of research conducted by Basarda et al., (2018), Dwi and Wardoyo (2019), and Akbar (2019) which concluded that interest rates have a positive effect on stock returns.

The results of the analysis show that interest rates have no effect on stock returns on the Indonesia Stock Exchange / IDX, and Frankfurt Stock Exchange / DAX. This shows that interest rates do not affect investors' decisions to invest in the capital market. The results of this study are in line with the results of research conducted by Hendrawan and Avitianti (2018), and Rafiq et al., (2019) which states that interest rates have no effect on stock returns.

\section{CONCLUSION}

First, based on the results of the study, it was found that the first Return on Equity / ROE had a positive effect on stock returns in the three capital markets studied, namely the Indonesia Stock Exchange, Frankfurt Stock Exchange, and the New York Stock Exchange. This explains that it is very important to consider the Return on Equity / ROE variable in making investment decisions in the Indonesia Stock Exchange, Frankfurt Stock Exchange, and New York Stock Exchange capital markets.

Second, based on the results of the study, it can be seen that Earning Per Share / EPS has a positive influence on stock returns on the New York Stock Exchange capital market, so that in making investment decisions investors consider the Earning Per Share / EPS variable in making investment decisions on the New York Stock Exchange capital market. Different research results found that Earning Per Share / EPS has no effect on stock returns on the Indonesia Stock Exchange and Frankfurt Stock Exchange so that in making investment decisions in the Indonesian Stock Exchange and Frankfurt Stock Exchange investors can ignore the Earning Per Share / EPS variable.

Third, based on the results of the study, it can be seen that the Debt to Equity Ratio / DER results 


\section{International Journal of Business Management and Economic Review}

Vol. 4, No. 04; 2021

ISSN: 2581-4664

of this study have shown that the Debt to Equity Ratio / DER has a negative effect on stock returns on the Indonesia Stock Exchange, so that in making investment decisions in the Indonesia Stock Exchange capital market, investors pay attention to debt to Equity Ratio / DER because it can provide an overview of the capital structure of the company so that it can be seen the level of risk of default from debt. Investors tend to avoid stocks with high Debt to Equity Ratio / DER values. Different results are shown by the results of research analysis on the Frankfurt Stock Exchange and the New York Stock Exchange, which show that the Debt to Equity Ratio / DER has no effect on stock returns. So that in making investment decisions on the Frankfurt Stock Exchange, and the New York Stock Exchange, investors can ignore the Debt to Equity Ratio / DER variable.

Fourth, based on the results of the study, it can be seen that GDP has no effect on stock returns in making investment decisions in the Indonesian Stock Exchange, Frankfurt Stock Exchange, and New York Stock Exchange capital markets.

Fifth, based on the results of research, interest rates have a positive effect on stock returns, as shown by the analysis conducted on the New York Stock Exchange, so that in making investment decisions, investors consider the interest rate factor in making investment decisions on the New York Stock Exchange capital market. In contrast to the analysis in the two other capital markets studied, namely the Indonesia Stock Exchange and the Frankfurt Stock Exchange, the results show that interest rates have no effect on stock returns.

\section{REFERENCES}

Abdallah, Shadi Yousef Al, \& ALjarayesh, Nada Ibrahim Abu. 2017. Influence of Interest Rate, Exchange Rate and Inflation On Common Stock Returns of Amman Stock Exchange, Jordan. International Journal of Economics, Commerce and Management United Kingdom, Financial and Business Administration and Computer Science Department, Al- Zarqa University College, Al-Balqa Applied University, Jordan. Vol. 5, Issue. 10, pp. 589-601.

Ahmad, M., Maochun, Z., \& Sattar, A. 2019. Impact of Interest Rate and Exchange Rate on Stock Returns. AGATHOS. College of Business Administration, Liaoning Technical University, China. Vol. 10, Issue. 1, pp. 259-266.

Akbar, A. B. 2019. An Analysis The Effect of Exchange Rate, Inflation and Interest On Stock Return. Jurnal Education and Economics (JEE). Collage of Economics Swasta Mandiri, Central Java, Indonesia. Vol. 2, No. 4, pp. 501-506.

Alarussi, A. S., \& Alhaderi, S. M. 2018. Factors affecting profitability in Malaysia. Journal of Economic Studies, University of Sussex Library.Vol. 45, No.3, pp. 442-458.

Allozi, N.M., \& Obeidat, G.S. 2016. The Relationship between the Stock Return and Financial Indicators (Profitability, Leverage): An Empirical Study on Manufacturing Companies Listed in Amman Stock Exchange. Journal of Social Sciences, Centre of Excellence for Scientific \& Research Journalism. Vol. 5, No. 3, pp. 2305-9494.

Anita, E., \& Negoro, D. A. 2019. Influence Analysis of Gross Domestic Product, Return on Equity, and Earning Share in Stock Price Using Moderating Variables Inflation over Consumer Goods Companies Indonesia Stock Exchange. Science, Engineering and Social Science Series, Department of Management, Faculty Economics and Business, Universitas Esa Unggul. Vol. 3, No. 04, pp. 114-122. 


\section{International Journal of Business Management and Economic Review}

Vol. 4, No. 04; 2021

ISSN: 2581-4664

Anwaar, Maryyam. 2016. Impact of Firms Performance on Stock Returns (Evidence from Listed Companies of FTSE-100 Index London, UK). Global Journal of Management and Business Research: D Accounting and Auditing. The University of Lahore, Pakistan. Vol. 16, No. 1, pp. 0975-5853.

Aryaningsih, Y. N., Fathoni, A., \& Harini, D.C. 2018. Pengaruh Return On Asset (ROA), Return On Equity (ROE) dan Earning Per Share (EPS) Terhadap Return Saham Pada Perusahaan Consumer Good (Food and Baverages) yang Terdaftar di BEI Periode 2013-2016. Jornal Of Management. Universitas Pandanaran Semarang. Vol. 4, No. 4, pp. 01-16.

Asad, Humaira,\& Cheema, F. K. 2017. An Empirical Assessment of the Q-Factor Model: Evidence from the Karachi Stock Exchange. The Lahore Journal of Economics. Institute of Business Administration, University of the Punjab, Lahore.Vol. 22, No.2, pp.117-138.

Astuty, Pudji. 2017. The Influence of Fundamental Factors and Systematic Risk to Stock Prices on Companies Listed in the Indonesian Stock Exchange. European Research Studies Journal. Faculty of Economics, University Borobudur Jakarta, Indonesia. Vol. 20, No. 4A, pp. 230-240.

Bannigidadmat, Deepa, \& Narayan, P. K. 2015. Stock Return Predictability and Determinants of Predictability and Profit. Emerging Markets Review. Vol. 26, pp. 153-173.

Basarda, R. F., Moeljadi, M., \& Indrawati, N. K. 2018. Macro and Micro Determinants of Stock Return Companies in LQ-45 Index. Jurnal Keuangan dan Perbankan, Department of Management Faculty of Economics and Business Brawijaya University, Indonesia. Vol. 22, No. 2, pp. $310-320$.

Brigham, Eugene F. \& Daves, Phillip R. 2019. Intermediate Financial Management 13th Edition. Cengage Learning, Inc.

Caroline, R. T. M. 2020. Effect of Return on Equity, Debt to Asset Ratio, Working Capital Turnover and Devidend Payout Ratio on Stock Return. Saudi Journal of Economics and Finance, Scholars Middle East Publishers, Dubai, United Arab Emirates. Vol. 4, No.8, pp. 384389.

Chasanah, A. N. 2021. Pengaruh Makroekonomi Terhadap Return Saham Pada Perusahaan Perbankan. Jurnal Ilmiah Ekonomi, Sekolah Tinggi Ilmu Ekonomi Pelita Nusantara, Semarang, Indonesia. Vol. 16, No.1, pp. 111-122.

Dwi, S. I. S., \& Wardoyo. 2021. Analysis of The Effect of Return On Assets, Earning Per Share, Inflation Rate, and Interest Rate On Stock Return: A Case Study of Soe Banking Companies Listed In Indonesia Stock Exchange. Russian Journal of Agricultural and Socio-Economic Sciences, University of Gunadarma, Jakarta, Indonesia. Vol. 1, No.85, pp. 24-34.

Egbunike, C. F. \& Okerekeoti, C. U. 2018. Macroeconomic factors, firm characteristics and financial performance: A study of selected quoted manufacturing firms in Nigeria. Asian Journal of Accounting Research, Nigeria.Vol. 3 No. 2, pp. 142-168.

Ekaprastyana, D., \& Anwar, S. 2017. The Effect of Earning Per Share and Debt to Asset Ratio on Firm's Value : Case Study on Food and Beverage Corporation Listed in Indonesia Stock Exchange. Jurnal Keuangan dan Perbankan, Sekolah Tinggi Ilmu Ekonomi Ahmad Dahlan.Vol. 13, No. 2, pp. 120-127.

Ghozali, Imam. 2014. Aplikasi Analisis Multivariate dengan Program IBM SPSS 21. Edisi ke-7. Semarang: Universitas Diponegoro.

Hamza, M., \& Jaradat, M. M. 2018. The Impact of Changes in the Elements of Cash Flows Statement on Stock Returns in Jordanian Commercial Banks Listed on Amman Stock Exchange: 


\section{International Journal of Business Management and Economic Review}

Vol. 4, No. 04; 2021

ISSN: 2581-4664

An Empirical Study. Journal of Accounting, Finance \& Management Strategy, Faculty of Economics and Administrative Science, Zarqa University. Vol. 13, No. 2, pp. 1-22.

Jogiyanto, Hartono. 2015. Teori Portofolio dan Analisis Investasi. BPFE: Yogyakarta.

Hertina, D., \& Saudi, M. H. M. 2019. Stock Return: Impact of Return on Asset, Return on Equity, Debt to Equity Ratio and Earning Per Share. International Journal of Innovation, Creativity and Change, Widyatama University Bandung, Indonesia. Vol. 6, No. 12, pp. 93-104. Hendrawan, Riko, \& Avitianti, Avi. 2018. LTV, Macro Economics and ROE to Stock Return in Real Estate and Property Companies Listed on LQ 45 Period 2009 - 2017. International Journal of Engineering \& Technology, Telkom University Bandung, Indonesia. Vol. 7, No. 4.38, pp. 852-855.

Jatmika, D.T., Sukoco, A., Suyono, J.,\& Damarsari, R.E. 2018. The Effect of Return On Asset, Return On Equity, and Earning Per Share In The Stock Prices of Tourism and Hospitality Companies Listed In The Indonesia Stock Exchange 2013-2017. Journal of World Conference, Departrement of Management, Faculty of Economics and Business, Narotama University, Surabaya, Indonesia. Vol. 1, No. 2, pp. 306-314.

Jayashankar, M. \& Rath, B. N. 2017. The dynamic linkage between exchange rate, stock price and interest rate in India. Studies in Economics and Finance, Cornell University Library. Vol. 34, No. 3, pp. 383-406.

Kamar, Karnawi. 2017. Analysis of the Effect of Return on Equity (Roe) and Debt to Equity Ratio (Der) On Stock Price on Cement Industry Listed In Indonesia Stock Exchange (Idx) In the Year of 2011-2015. Journal of Business and Management, STIE Insan Pembangunan, Tanggerang, Banten. Vol. 19, No. 5, pp. 66-76.

Kasmir. 2012. Analisis Laporan Keuangan. Jakarta : PT. Raja Grafindo Persad.

Khan, M. T., Khan, A., Ahmad, Dr. A., \& Bashir, O. U. 2018. Impact of Macroeconomic Factors on Stock Returns of KSE 100 Index. Journal of Business and Tourism, Institute of Business Studies and Leadership Abdul Wali Khan University, Mardan. Vol. 04, No. 1, pp. 133-145.

Lazar, Sebastian. 2016. Determinans of Firm Performance: Evidence From Romanian Listed Companies. Faculty of Economics and Business Administration, University Alexandru Ioan Cuza of Iași, Romania. Vol. 6, Issue. 1, pp. 53-69.

Marandu, K.R. \& Sibindi, A.B. 2016. Capital Structure and Profitability: An Empirical Study Of South Africans Banks. University of South Africa; Department of Finance, Risk Management and Banking.Vol.14, No. 1, pp. 8-19.

Nurhikmawaty, D., Isnurhadi, W. M., \& Yuliani. 2020. The Effect of Debt to Equity Ratio and Return on Equity on Stock Return With Deviden Policy as Intervening Variabel in Subsector Property and Real Estate on BEI. Magister Programme of Management, Faculty of Economics, Universitas Sriwijaya, Indonesia. Vol. 8, No. 2, pp. 72-85.

Rafiq, M. Z., Jun, J. C., Naseem, S., \& Mohsin, M. 2019. Impact of Market Risk, Interest rate, Exchange rate on Banks stock return: Evidence from listed Banks of Pakistan. Amazonia Investiga, de los bancos de, Pakistán.Vol. 8, No. 21, pp. 667-673.

Ratih, I. G. A. A. N., \& Candradewi, M. R. 2020. The Effect of Exchange Rate, Inflation, Gross Domestic Bruto, Return on Assets, and Debt to Equity Ratio on Stock Return in LQ45 Company. American Journal of Humanities and Social Sciences Research (AJHSSR), Fakultas Ekonomi dan Bisnis, Universitas Udayana (Unud), Bali, Indonesia.Vol. 4, No. 6, pp. 170-177. 


\section{International Journal of Business Management and Economic Review}

Vol. 4, No. 04; 2021

ISSN: 2581-4664

Sami, R. M. 2018. Exploring the Relationship between Financial Ratios and Market Stock Returns. Eurasian Journal of Business and Economics, International University of Sarajevo (IUS), Sarajevo, Bosnia and Herzegovina.Vol. 11, No. 21, pp. 101-116.

Sausan, F. R., Korawijayanti, L., \& Ciptaningtias, A. F. 2020. The Effect of Return on Asset (ROA), Debt to Equity Ratio (DER), Earning per Share (EPS), Total Asset Turnover (TATO) and Exchange Rate on Stock Return of Property and Real Estate Companies at Indonesia Stock Exchange Period 2012-2017. Ilomata International Journal of Tax \& Accounting, Program Studi Akuntansi Manajerial Jurusan Akuntansi Politeknik Negeri Semarang, Indonesia. Vol. 1, No. 2 , pp. 103-114.

Sugiyono. 2019. Metodologi Penelitian Kuantitatif, Kualitatif dan R\&D, CV Alfabeta, Bandung. Suhadak, K., Handayani, S. R., \& Rahayu, S. M. 2018. Stock return and financial performance as moderation variable in influence of good corporate governance towards corporate value. Asian Journal of Accounting Research, Department of Business Administration, Faculty of Adminisrative Science, Brawijaya University, Malang, Indonesia.Vol. 4, No. 1, pp. 18-34.

Suyana Utama, Made. 2007. Aplikasi Analisis Kuantitatif. Denpasar: Sastra Utama.

Tascha, D. S., \& Mustafa, M. H. 2021. Analysis of The Effect of Financial Performance and Macro Economic Factors On The Return of Food \& Beverage Stock Companies In Indonesia Stock Exchange For The Period 2015-2019. Dinasti International Journal of Education Management and Social Science, Master of Management, Mercu Buana University Jakarta, Indonesia.Vol. 2, Issue. 4, pp. 587-595.

Tandelilin, Eduardus. 2010. Portofolio dan Investasi Teori dan Aplikasi. Edisi pertama. Yogyakarta : Kanisius.

Thrun, M. C. 2019. Cluster Analysis of Per Capita Gross Domestic Products. Entrepreneurial Business and Economics Review, Philipps-University of Marburg, Hans-MeerweinStraße 6, D35032 Marburg, Germany. Vol. 7, No. 1, pp. 217-231.

Wikipedia. 2020. Harga Saham. [cited 2021 Maret.5]. Available from : URL :https://id.wikipedia.org/wiki/Harga_saham\#: :text=Harga\%20saham\%20adalah\%20harga\%20y ang,antara\%20penjual\%20dan\%20pembeli\%20saham.

Zhang, B., Yuan, H., and Zhi, X. 2017. ROE as a performance measure in performance-vested stock option contracts in China. Frontiers of Business Research in China School of Business, Renmin University of China, Beijing 100872, China. Vol. 11, No. 4, pp. 1-17 